\title{
The COVID-19 Pandemic-Implications for the Cytology Laboratory
}

\section{IJCRR}

Section: Healthcare

Sci. Journal Impact

Factor: 6.1 (2018)

ICV: 90.90 (2018)

(c) (i) (8)

Copyright@IJCRR

\section{Padma Priyaa N.. ${ }^{1}$ Brundha M. P. ${ }^{2}$, Smiline Girija AS $^{3}$}

'Saveetha Dental College and Hospitals, Saveetha Institute of Medical and Technical Sciences, Saveetha University, Chennai-77, India; ${ }^{2}$ Associate Professor, Department of Pathology, Saveetha Dental College and Hospitals, Saveetha Institute of Medical and Technical Sciences, Saveetha University, Chennai-60oo77, India; ${ }^{3}$ Associate Professor, Department of Microbiology, Saveetha Dental College and Hospitals, Saveetha Institute of Medical and Technical Sciences, Saveetha University, Chennai-60oo77, India.

\section{ABSTRACT}

Aim and Objectives: To review the current state of the knowledge about the COVID-19 cytological aspects.

Background: The coronavirus disease 2019 (COVID-19) is a pandemic caused by the SARS-CoV2 virus. The infection has a predominantly respiratory transmission and it is transmitted through large droplets or aerosols, and less commonly with the infected surface or fomites. The widespread infection led to social distancing measures. Because it's miles brought about by a singular virus, the cutting-edge pandemic has created plenty of anxiety, a good deal of it because of the comprehensible fear of the unknown. We do no longer know how lengthy this pandemic will last, and what its toll on groups will be in terms of fatalities, or in psychological, physical, and economic well-being. At this time, we still have many unanswered questions about this virus. For a number of these questions, we won't have answers primarily based on hard information for months to come, maybe until the epidemic is over and an analysis of the worldwide records may be performed. Nonetheless, even before we have all the answers, we should neither panic, nor deal with it too lightly. We have to "hold calm and bring on" and hold to characteristic as a cytology laboratory committed to offering the exceptional provider to our sufferers in this health care emergency, however at the same time maximize the protection of fitness care people and prevent useless risks, which could help the dissemination of the virus. Due to repeated exposure to infectious patients and specimens, health care workers and laboratory personnel are more susceptible to COVID-19.

Discussion and Conclusion: This review paper provides an assessment of the current state of knowledge about the disease, its pathology, and the potential presence of the virus in the cytology samples. It also discusses the measures to be taken in the cytology laboratory during the pandemic and reduces the risk of the pathologist, personnel, and trainees.

Key Words: Implications of cytology lab, Cytopathological specimens, Measures to prevent COVID-19

\section{INTRODUCTION}

The COVID-19 is a pandemic disease caused by the SARS $\mathrm{CoV}-2$ virus. The infection is a respiratory transmission and it is transmitted through the droplets and the aerosols, and very less percentage through contact or articles used by the infected person. Social distancing measures have been taken to get rid of the infection. Nowadays there are more risks to the lives of health care and laboratory personnel who handle the specimens of infectious patients and they are particularly susceptible to this pandemic disease. ${ }^{1}$ The COVID19 is a pandemic disease caused by the SARS CoV-2 virus. The first case was reported in late 2019 in Wuhan, these coronaviruses that cause severe respiratory infections are transmitted from animals to humans (zoonotic pathogens). Cities that followed the method of social distancing had fewer mortality rates $^{2}$. For instance, COVID-19 is infectious even during the pre-symptomatic phase. Also, physiological processes that are harmful in one phase of the disease may become helpful later. For example, the angiotensin-converting enzyme-2 (ACE-2) receptor, which allows the virus to enter the body, may also be key to the protection of the lungs in the later phases of the disease $\mathrm{e}^{3}$. Coronavirus got their name from the club-formed protein spikes on their surface, which give the presence of a crown or "crown" in the 2-dimensional picture of transmission electron microscopy. They are fairly huge (120 nm), wrapped positive-sense single-abandoned RNA infections. Their particular tissue tropism, infectivity, and species go are presented by the spike protein, which connects with a particular cell receptor. On account of SARS-

\section{Corresponding Author:}

Dr. M. P. Brundha, Associate Professor, Department of Pathology, Saveetha Dental College and Hospitals, Saveetha Institute of Medical and Technical Sciences, Saveetha University, Chennai-600077, India; Contact: +919884421482; Email: brundha.sdc@saveetha.com

ISSN: 2231-2196 (Print)

Received: 18.08 .2020
ISSN: $0975-5241$ (Online)

Revised: 14.09 .2020
Accepted: 16.10 .2020 
CoV and SARS-CoV-2, the receptor for the infection is the angiotensin-changing over compound 2 (ACE2) receptor on ciliated bronchial epithelial cells, though for MERS$\mathrm{CoV}$, the receptor is DPP4/CD26 on non-ciliated respiratory epithelial cells, ${ }^{1}$ recent study showed that $0.2 \%$ of healthy adult blood donors in Saudi Arabia have specific antibodies against MERS-CoV, suggesting the existence of a large number of asymptomatic or mild infections, which may act as an unrecognized source of infection ${ }^{4}$

\section{CYTOLOGY LABORATORY FOR COVID-AN OVERVIEW}

\section{Comparison of COVID With Other Corona Out- breaks}

Apart from the COVID19 outbreak in China, there are several other respiratory diseases caused by a coronavirus. They are the severe acute respiratory syndrome coronavirus (SARS-CoV) and the Middle East respiratory syndromerelated coronavirus (MERS-CoV). These are all the members of beta coronavirus genes. Both SARS-CoV and SARSCoV2 viruses appear to originate from animals, mostly from bats, the mammals with the highest diversity of coronavirus. The transmission may have resulted through the intermediatory of civets, the pangolin, or other animals. This shows that SARS-CoV2 has a remarkable $96 \%$ generic hematology with a corona from bat coronavirus ${ }^{5}$, and $99 \%$ sequence hematology from pangolin species ${ }^{6}$, MERS-CoV probably originated from bats ${ }^{7}$, but intermediate host is dromedary camels. Camels to the human transmission may occur through camel milk, and medicinal use of camel urine ${ }^{8}, 9$ three diseases have similar but not identical, clinical manifestations, spanning the entire range from mild feels like symptoms to severe pneumonia and acute respiratory distress syndrome.

High numbers of asymptomatic or minimally symptomatic infections probably occurred during the SARS epidemic, also a meta-analysis shows that overall seroprevalence rates are $0.1 \%$ for the general population and $0.23 \%$ for healthcare workers $^{10}$

\section{Lab Findings}

Laboratory findings are nonspecific but usually include leukocytosis with lymphopenia, mainly increased liver symptoms, enzymes, muscle enzymes, myoglobin, lactate dehydrogenase and increase in acute phase reactants. Increased procalcitonin, severe lymphopenia, and elevated D-dimers were features that correlated with more severe disease. In severe cases, the disease may progress to respiratory, circulatory, and renal failure, and ultimately death due to multiorgan failure ${ }^{11}$.

\section{Pathological Findings}

The few reports documenting the findings of COVID-19 show that the pathology is dominated by pulmonary findings, including pulmonary edema and prominent proteinaceous exudates, vascular congestion, and intra-alveolar fibrinoid material and various degrees of organization (fibroblastic plugs) corresponding to acute pulmonary injury patterns. In addition, there may be reactive type-II pneumocyte hyperplasia, and atypical enlarged pneumocytes with large nuclei, amphophilic granular cytoplasm, but no definite intranuclear or cytoplasmic viral inclusions were identified. ${ }^{1,12}$ The inflammatory infiltrate is predominantly lymphocytic without significant neutrophil participation ${ }^{13}$. Immunohistochemistry for the Rp3 NP protein of SARS-CoV-2 showed staining of alveolar epithelial cells, including the damaged, desquamated cells present within alveolar spaces, ${ }^{14}$ but viral protein expression was only minimal in endothelial cells. This finding is similar to that seen in MERS, where immunohistochemistry with 4 antibodies against MERS-CoV showed the presence of the virus scattered in cytokeratin-staining pneumocytes and syncytial cells, but not in CD68-positive macrophages. ${ }^{15}$

\section{Clinical Specimens: Novel Coronavirus}

All testing for SARS-CoV-2 should be conducted in consultation with a health care provider, specimens should be collected as soon as possible once a decision has been made to pursue testing, regardless of the time of symptom onset ${ }^{16}$. For initial diagnostic testing of SARS-CoV-2 CDC recommendations collecting and testing an upper $\mathrm{r}$ specimen $^{17}$. The subs collected should be placed immediately into sterile transport tubes containing 2-3 $\mathrm{mL}$ of either viral transport medium (VTM), Amies transport medium, or sterile saline, unless using a test designed to analyze a specimen directly, such as the same point of case tests. If VTM is not available, see the standard operating procedure for public health labs to create a viral transport medium in accordance with CDC's protocol. The new specimen and the non-bacteriostatic saline used to collect the specimen tube should be placed into a sterile transport tube ${ }^{18}$.

For patients who develop a productive cough, sputum should be collected and tested for SARS CoV-2. The induction of sputum is not recommended, when under certain clinical circumstances a lower respiratory tract aspirate or BAL sample should be collected and tested as lower respiratory tract specimen ${ }^{19}$. The severity of disease greatly affected the cellular composition of BAL-samples, where the mild disease was associated with higher proportions of natural killer (NK) and CD8 T cells but lower levels of macrophage recruitment than severe disease. In addition to detecting more T-cells in BALF from patients with mild-disease, researchers also detected increased clonal expansion in mild disease compared to severe-disease. Further CD8 T-cells detected expressed 
high transcriptomic levels of cytotoxic molecules, suggesting a crucial role of cytotoxic $\mathrm{T}$ cells in immunity and clearance of SARS-CoV2

In summary, this is the first reported study on the cellular atlas of lung broncho-alveolar immune microenvironment in COVID-19 patients. Results presented by Liao et al., "unveiled potential immune mechanisms underlying disease progression and protection in COVID-19 patients." ${ }^{20}$. However, BAL and sputum indications are aerosol-generating procedures that should be performed only with careful consideration of the risk to staff aerosol generation. Endotracheal aspirates appear to carry a lower risk of aerosolization than BAL and are thought by some experts to have comparable sensitivity and specificity to BAL specimens ${ }^{20,21}$.

\section{SARS CoV-2 and the Cytology Laboratory}

Our response to the COVID-19 pandemic can be regarded at the society level, hospital level, laboratory level, and individual level. At the society level, local, state, and federal governments have instituted travel bans, and either governments or various organizations have introduced restrictions or cancelled larger gatherings, including sports events and cultural events (music, theater, cinema), and even political rallies. These measures are meant mostly as a mitigation strategy, to limit transmission, and to prevent the fast spread of the virus, and "level the infection curve" to prevent overwhelming the healthcare system.

At the level of hospitals and other health care institutions, decisions are made to prioritize the essential healthcare workers and reduce elective outpatient visits and inpatient admissions for elective interventions or operations. These measures are meant both to decrease the risk of infection to patients with routine annual and preventive health visits and elective procedures, and to increase the available capacity of the hospitals in case of a large surge of infections ${ }^{22}$.

The above-mentioned hospital measures to limit activities that can be safely ${ }^{23}$ postponed will undoubtedly affect the cytology laboratory, which will receive fewer specimens. This gives the cytology laboratory an opportunity to reevaluate their staffing needs and perhaps change the workflow. Measures may include working in shifts, and staggered meal breaks, to avoid contact between people, and having only the strictly necessary personnel in the laboratory. Clearly, any person having respiratory symptoms that could be caused by COVID-19 should not come to work and should instead consult their physician or healthcare professional ${ }^{24}$.

Emergency plans and contingency plans should be made for the possibility that a large proportion of the laboratory personnel has either fallen ill or is under quarantine. Communicating any changes or delays in service to the clinical service providers and departments is particularly important, to avoid overwhelming the laboratory with inquiries about test results.

The role of the cytology laboratory in a patient with known COVID-19 is limited. In analogy to the role of the cytology laboratory in SARS, it is mainly to rule out superimposed pulmonary infections in sputum and other respiratory specimens. The cytologic features seen in sputa are nonspecific and reflect the underlying acute pulmonary injury pattern. They consist of the presence of an increased number of macrophages, forming loose macrophage aggregates. The macrophages may also show cytoplasmic changes, including the presence of foamy cytoplasm or larger cytoplasmic vacuoles or nuclear changes, including multi-nucleation and ground glass appearance of nuclei, because bronchoalveolar lavage (BAL) fluid is sometimes obtained for viral identifica$\operatorname{tion}^{25,26,27}$.

\section{Laboratory Measures}

Given the extraordinarily fast spread of the disease and the pace of change in the information about it and guidelines on how to deal with various aspects of fighting it, one can only give general suggestions for the cytology laboratory's response as mentioned below. The recommendations are similar to those given for general and histopathology laboratories, ${ }^{28-30}$ but also include the situations in which cytology laboratory personnel is involved either in the care of patients potentially infected with SARS-CoV-2 during FNA procedures or rapid-onsite evaluation of aspiration or core biopsies $^{31,32}$ or in the preparation of fresh specimens from such patients, the measures are review your procedures and reduce or eliminate steps that could result in aerosol formation or creation of droplets, review the indications for rapid onside evaluations (ROSE), and reassess their need after discussions with the provides requesting these services, to eliminate unnecessary exposure, establish a chain of command, emergency plan, and contingency plan, reassess the situation weekly or biweekly and make any changes necessary, implement measures to reduce crowding: review staffing and realign staffing needs with the workload; consider working in shifts to reduce overlap, Follow $\mathrm{CDC} / \mathrm{WHO}$ guidelines for routine specimen processing in accordance to biosafety level 2 guidelines, Process all specimens that have steps that could result in aerosols or droplets (including making smears, staining them and air-drying or heat fixing them), in a class II biosafety cabinet (BSC) ${ }^{33}$, Follow any additional or updated CDC guidelines, Keep informed about the latest developments regarding the COVID-19 pandemic and inform the staff about any new scientific knowledge; dispel misconceptions, Keep informed about the newest hospital policies and procedures and inform the staff of any changes, Keep open communication channels with colleagues and staff and provide a virtual community through daily "fireside chats", including people working from home. The patients visiting 
dental clinics may have systemic medical conditions and are on medication or without medication ${ }^{34}$, this should be checked properly and the reports can be sent through mail ${ }^{35}$ to avoid pandemic. The hematological reports were important to general populations. ${ }^{36,37}$ Do's and don't cause unnecessary concerns or panic, but be frank about the risks. Don't disseminate or endorse rumors or information not coming from a reputable source (CDC, FDA, WHO, peer-reviewed publication).

\section{Special Precautions}

Special precautions should be taken in handling specimens for which the preparation involves steps that can lead to aerosol formation. All technical procedures should be performed in a way that minimizes the generation of aerosols and droplets. Preparatory steps that may generate aerosols or droplets include expelling aspirates from the needle or syringe; smearing the aspirated material; and potentially, air-drying or heat drying the smears, ${ }^{38}$ in which pathologists, trainees, or cytotechnologists may be involved during rapid on-site evaluation (ROSE). Air-drying or heat drying of smears is best performed under Class II Biosafety Cabinets (BSC) ${ }^{39,40} \mathrm{Agitating}$ the smears by hand or using hand-held fans to speed up the drying of smears should be avoided. ROSE is an important measure to ensure the adequacy of specimens. However, during an epidemic of a virus with respiratorytransmission, like SARS-CoV-2, clinical judgment should be used to determine whether ROSE is absolutely necessary for the success of the biopsy procedure ${ }^{41}$.

If ROSE is performed, it should be performed with appropriate personal protective equipment (PPE) including gloves, laboratory coat/gown, and goggles or face shields for eye protection and respiratory protection using a properly fittested filter respirator (N-95 or higher level) or a powered air-purifying respirator ${ }^{42}$. The anticipated shortage of face masks and filter respirators ${ }^{43}$. General safe lab procedures should be followed, hand washing techniques should be followed which is as recommended by WHO and CDC ${ }^{44}$.

The virus is inactivated by formalin and gamma irradiation. Therefore, according to the Centers for Disease Control and Prevention (CDC) guidelines, ${ }^{45}$ cytology laboratory activities, such as the pathologic examination and processing of formalin-fixed or otherwise inactivated tissues (cell block preparations), and the routine staining and microscopic analysis of fixed smears are assigned biosafety level 2 . This is the typical biosafety level of all pathology laboratories and is assigned when working with agents associated with human diseases that pose a moderate health hazard or when working with any human-derived sample ${ }^{46}$, including blood, body fluids, or tissue, in which the presence of an infectious agent is unknown ${ }^{47}$. Most cytology specimens are fixed in either formalin or alcohol solutions with over $70 \%$ alcohol, which is considered effective to destroy this virus. It is not known whether fixatives using much weaker alcohol solutions, such as PreservCyt and CytoLyt are adequately inactivating the virus. Therefore additional precautions ${ }^{48}$, like the use of gloves, maybe indicated while handling and interpreting cytologic preparations processed with these fixatives. Some pathologists may prefer using gloves for all their slides, since glass slides are touched by multiple hands until they reach the pathologist's desk, and cannot be easily decontaminat$\mathrm{ed}^{49}$. Although dipping the slides in $95 \%$ alcohol (or similar) for a couple of minutes would inactivate the virus, it would also erase the marks ("dots") on the slides. Other surface disinfectants, especially ones with short contact times, as mentioned later in this paper, can be tried to determine the practicality of their use on cytology slides.

\section{CONCLUSION}

As prevention is better than cure, several frameworks and rules are formulated by the WHO, CDC and the government should be followed efficiently in all the cytology laboratories. This prevents the spread of infection among the lab technicians and other health care workers who are involved in the frontline screening protocols of the disease. In this COVID pandemic, it is thus imperative to frame guidelines in a cytology laboratory to limit patients' visits, appointments in hospital, prioritize the preliminary screening protocols and frame the emergency plans towards hospitalization.

\section{ACKNOWLEDGMENT}

Authors acknowledge the immense help received from the scholars whose articles are cited and included in references to this manuscript. The authors are also grateful to authors / editors / publishers of all those articles, journals, and books from which the literature for this article has been reviewed and discussed.

\section{Conflict of Interest: Nil}

\section{Source of Funding: Nil}

\section{REFERENCES}

1. Pambuccian SE. The COVID-19 pandemic: implications for the cytology laboratory [Internet]. Vol. 9, Journal of the American Society of Cytopathology. 2020. p. 202-11. Available from: http://dx.doi.org/10.1016/j.jasc.2020.03.001

2. Markel H, Lipman HB, Alexander Navarro J, Sloan A, Michalsen JR, Stern AM, et al. Nonpharmaceutical Interventions Implemented by US Cities During the 1918-1919 Influenza Pandemic [Internet]. Vol. 298, JAMA. 2007. p. 644. Available from: http:// dx.doi.org/10.1001/jama.298.6.644

3. Johnson NPAS, Niall P A, Mueller J. Updating the Accounts: Global Mortality of the 1918-1920 "Spanish" Influenza Pandemic [Internet]. Vol. 76, Bulletin of the History of Medicine. 
2002. p. 105-15. Available from: http://dx.doi.org/10.1353/ bhm.2002.0022

4. Degnah AA, Al-amri SS, Hassan AM, Almasoud AS, Mousa M, Almahboub SA, et al. Seroprevalence of MERS-CoV in healthy adults in western Saudi Arabia, 2011-2016 [Internet]. Vol. 13, Journal of Infection and Public Health. 2020. p. 697-703. Available from: http://dx.doi.org/10.1016/j.jiph.2020.01.001

5. Zhou P, Yang X-L, Wang X-G, Hu B, Zhang L, Zhang W, et al. A pneumonia outbreak associated with a new coronavirus of probable bat origin [Internet]. Vol. 579, Nature. 2020. p. 270-3. Available from: http://dx.doi.org/10.1038/s41586-020-2012-7

6. Yang Y, Peng F, Wang R, Yang M, Guan K, Jiang T, et al. Corrigendum to "The deadly coronaviruses: The 2003 SARS pandemic and the 2020 novel coronavirus epidemic in China". J Autoimmun. $2020 \mathrm{Jul} ; 111: 102487$.

7. Immune responses in COVID-19 and potential vaccines: Lessons learned from SARS and MERS epidemic [Internet]. Asian Pacific Journal of Allergy and Immunology. 2020. Available from: http://dx.doi.org/10.12932/ap-200220-0772

8. Sayed ASM, Malek SS, Abushahba MFN. Seroprevalence of Middle East Respiratory Syndrome Corona Virus in dromedaries and their traders in upper Egypt [Internet]. Vol. 14, The Journal of Infection in Developing Countries. 2020. p. 191-8. Available from: http://dx.doi.org/10.3855/jidc.10862

9. Wang Y, Sun J, Li X, Zhu A, Guan W, Sun D-Q, et al. Increased Pathogenicity and Virulence of Virus in Middle East Respiratory Syndrome Coronavirus Clade B and. J Virol [Internet]. 2020 May 20; Available from: http://dx.doi.org/10.1128/JVI.0086120

10. Leung GM, Lim WW, Ho L-M, Lam T-H, Ghani AC, Donnelly $\mathrm{CA}$, et al. Seroprevalence of IgG antibodies to SARS-coronavirus in asymptomatic or subclinical population groups. Epidemiol Infect. 2006 Apr;134(2):211-21.

11. Bai HX, Hsieh B, Xiong Z, Halsey K, Choi JW, Tran TML, et al. Performance of radiologists in differentiating COVID-19 from viral pneumonia on chest CT [Internet]. Radiology. 2020. p. 200823. Available from: http://dx.doi.org/10.1148/radiol.2020200823

12. Xu Z, Shi L, Wang Y, Zhang J, Huang L, Zhang C, et al. Pathological findings of COVID-19 associated with acute respiratory distress syndrome [Internet]. Vol. 8, The Lancet Respiratory Medicine. 2020. p. 420-2. Available from: http://dx.doi. org/10.1016/s2213-2600(20)30076-X

13. Yao XH, Li TY, He ZC, Ping YF, Liu HW, Yu SC, et al. [A pathological report of three COVID-19 cases by minimal invasive autopsies]. Zhonghua Bing Li Xue Za Zhi. 2020 May 8;49(5):411-7.

14. Tian S, Hu W, Niu L, Liu H, Xu H, Xiao S-Y. Pulmonary Pathology of Early Phase 2019 Novel Coronavirus (COVID-19) Pneumonia in Two Patients with Lung Cancer [Internet]. Available from: http://dx.doi.org/10.20944/preprints202002.0220.v2

15. Zhang H, Zhou P, Wei Y, Yue H, Wang Y, Hu M, et al. Histopathologic Changes and SARS-CoV-2 Immunostaining in the Lung of a Patient With COVID-19 [Internet]. Vol. 172, Annals of Internal Medicine. 2020. p. 629-32. Available from: http:// dx.doi.org/10.7326/m20-0533

16. Ng DL, Al Hosani F, Kelly Keating M, Gerber SI, Jones TL, Metcalfe MG, et al. Clinicopathologic, Immunohistochemical, and Ultrastructural Findings of a Fatal Case of Middle East Respiratory Syndrome Coronavirus Infection in the United Arab Emirates, April 2014 [Internet]. Vol. 186, The American Journal of Pathology. 2016. p. 652-8. Available from: http://dx.doi. org/10.1016/j.ajpath.2015.10.024
17. Wang W, Xu Y, Gao R, Lu R, Han K, Wu G, et al. Detection of SARS-CoV-2 in Different Types of Clinical Specimens [Internet]. JAMA. 2020. Available from: http://dx.doi.org/10.1001/ jama.2020.3786

18. Hamzelou J. Wuhan virus spreads [Internet]. Vol. 245, New Scientist. 2020. p. 7. Available from: http://dx.doi.org/10.1016/ s0262-4079(20)30139-1

19. Masrul M, Abdillah LA, Tasnim T, Simarmata J, Daud D, Sulaiman OK, et al. Pandemik COVID-19: Persoalan dan Refleksi di Indonesia. Yayasan Kita Menulis; 2020. 198 p.

20. Liao M, Liu Y, Yuan J, Wen Y, Xu G, Zhao J, et al. The landscape of lung bronchoalveolar immune cells in COVID-19 revealed by single-cell RNA sequencing [Internet]. Available from: http:// dx.doi.org/10.1101/2020.02.23.20026690

21. Hase R, Kurita T, Muranaka E, Sasazawa H, Mito H, Yano Y. A case of imported COVID-19 diagnosed by PCR-positive lower respiratory specimen but with PCR-negative throat swabs [Internet]. Vol. 52, Infectious Diseases. 2020. p. 423-6. Available from: http://dx.doi.org/10.1080/23744235.2020.1744711

22. Sorino C, Magrì D, Oliviero G, Milani G. Clinical Utility and Interpretation of Laboratory Tests in Respiratory Medicine [Internet]. Diagnostic Evaluation of the Respiratory System. 2017. p. 28-28. Available from: http://dx.doi.org/10.5005/jp/ books/13029_4

23. Swetha S, Brundha MP. Analysis of knowledge about the hospital warning symbols among the postgraduate dental studentsA comparative study [Internet]. Vol. 10, Research Journal of Pharmacy and Technology. 2017. p. 975. Available from: http:// dx.doi.org/10.5958/0974-360x.2017.00177.9

24. Varshini A, Leslie Rani* S, Brundha MP. Awareness of annual doctor checkups among general population. Drug Invention Today. 2020 Mar 27;274-8.

25. National Academies of Sciences, Engineering, and Medicine, Health and Medicine Division, Board on Global Health, Committee on Global Health and the Future of the United States. Global Health and the Future Role of the United States. National Academies Press; 2017. 384 p.

26. Yu F, Du L, Ojcius DM, Pan C, Jiang S. Measures for diagnosing and treating infections by a novel coronavirus responsible for a pneumonia outbreak originating in Wuhan, China [Internet]. Vol. 22, Microbes and Infection. 2020. p. 74-9. Available from: http://dx.doi.org/10.1016/j.micinf.2020.01.003

27. Winichakoon P, Chaiwarith R, Liwsrisakun C, Salee P, Goonna A, Limsukon A, et al. Negative Nasopharyngeal and Oropharyngeal Swabs Do Not Rule Out COVID-19 [Internet]. Vol. 58, Journal of Clinical Microbiology. 2020. Available from: http:// dx.doi.org/10.1128/jcm.00297-20

28. Iwen PC, Stiles KL, Pentella MA. Safety Considerations in the Laboratory Testing of Specimens Suspected or Known to Contain the Severe Acute Respiratory Syndrome Coronavirus 2 (SARS-CoV-2) [Internet]. Vol. 51, Laboratory Medicine. 2020. p. 239-42. Available from: http://dx.doi.org/10.1093/labmed/ Imaa018

29. Henwood AF. Coronavirus disinfection in histopathology [Internet]. Journal of Histotechnology. 2020. p. 1-3. Available from: http://dx.doi.org/10.1080/01478885.2020.1734718

30. Tan SS, Yan B, Saw S, Lee CK, Chong AT, Jureen R, et al. Practical laboratory considerations amidst the COVID-19 outbreak: early experience from Singapore [Internet]. Journal of Clinical Pathology. 2020. p. jclinpath - 2020. Available from: http:// dx.doi.org/10.1136/jclinpath-2020-206563

31. Prashaanthi N, Brundha MP. A Comparative Study between Popplet Notes and Conventional Notes for Learning Pathology [In- 
ternet]. Vol. 11, Research Journal of Pharmacy and Technology. 2018. p. 175. Available from: http://dx.doi.org/10.5958/0974360x.2018.00032.x

32. Brundha MP, Pathmashri VP, Sundari S. Quantitative Changes of Red Blood cells in Cancer Patients under Palliative Radiotherapy-A Retrospective Study. Research Journal of Pharmacy and Technology. 2019;12(2):687-92.

33. Brundha MP, Haritha PS. Awareness of dengue fever among the parents of children coming to the dental outpatient department - A questionnaire study [Internet]. Vol. 3, International Journal of Clinicopathological Correlation. 2019. p. 60. Available from: http://dx.doi.org/10.4103/ijcpc.ijcpc_14_19

34. Shreya S, Brundha MP. Alteration of Haemoglobin Value in Relation to Age, Sex and Dental Diseases-A Retrospective Correlation Study. Research Journal of Pharmacy and Technology. 2017;10(5):1363-6.

35. Brundha MP, Nallaswamy D. Hide and seek in pathology- A research on game-based histopathology learning. IJRPS. 2019 Apr 29;10(2):1410-4.

36. Harsha L, Brundha MP. Prevalence of dental developmental anomalies among men and women and its psychological effect in a given population. Journal of Pharmaceutical Science and Research. 2017;9(6):869-73.

37. Saivignesh S, Brundha MP. Myeloid sarcoma. International Journal of Clinicopathological [Internet]. 2019; Available from: http://www.ijcpc.org/article.asp?issn=2589-1731; year=2019; vo lume $=3$; issue $=2 ;$ spage $=41$; epage $=43$; aulast $=$ Saivignesh

38. Hannah R, Ramani P, Brundha MP, Sherlin, Herald. J, Ranjith G, Ramasubramanian A, et al. Liquid Paraffin as a Rehydrant for Air Dried Buccal Smear. Research Journal of Pharmacy and Technology. 2019;12(3):1197-200.

39. Visha MG, Brundha MP. A review on ankylosing spondylitis. International Journal of Clinicopathological [Internet]. 2019; Available from: http://www.ijcpc.org/article.asp?issn=25891731; year $=2019$; volume $=3$; issue $=2$; spage $=44$; epage $=49$; aulast $=$ Visha
40. John DA, Brundha MP. Awareness of Vitamin A Deficiency among Middle Aged Men-Research. Vitamins \& Minerals. 2016;5(2):144.

41. Balaji S, Brundha MP, Path DNB. Awareness of About Breast Cancer among Dental Surgeons. Res J Pharm Biol Chem Sci. 2016;8(8):797.

42. Kalaiselvi R, Brundha MP. Prevalence of hysterectomy in South Indian population [Internet]. Vol. 9, Research Journal of Pharmacy and Technology. 2016. p. 1941. Available from: http:// dx.doi.org/10.5958/0974-360x.2016.00398.x

43. Kumar MD, Brundha MP. Awareness about nocturia-A questionnaire survey. Research Journal of Pharmacy and Technology. 2016;9(10):1707-9.

44. Preethikaa S, Brundha MP. Awareness of diabetes mellitus among general population. Research Journal of Pharmacy and Technology. 2018;11(5):1825-9.

45. Timothy CN, Samyuktha PS, Brundha MP. Dental pulp Stem Cells in Regenerative Medicine - A Literature Review [Internet]. Vol. 12, Research Journal of Pharmacy and Technology. 2019. p. 4052. Available from: http://dx.doi.org/10.5958/0974360x.2019.00698.x

46. Ferdioz J, Brundha MP. Awareness of stye. International Journal of Pharmaceutical Sciences Review and Research. 2016 Jan $1 ; 40(1): 30-2$.

47. Brundha MP. A Comparative Study-The Role of Skin and Nerve Biopsy in Hansen's Disease. Res J Pharm Biol Chem Sci. 2015;7(10):837.

48. Shenoy PB, Brundha MP. Awareness of polycystic ovarian disease among females of age group 18-30 years. Res J Pharm Biol Chem Sci. 2016;8(8):813.

49. Ravichandran H, Brundha MP. Awareness about personal protective equipments in hospital workers (sweepers and cleaners). International Journal of Pharmaceutical Sciences Review and Research. 2016;40(1):28-9. 